\title{
Persepsi Jamaah Mengenai Fasilitas dan Biaya dalam Memilih Jasa Umroh
}

\author{
Nurali Agus Najibul Zamzam ${ }^{1}$, Udik Jatmiko² \\ Program Studi Manajemen, Universitas Islam Kadiri Kediri ${ }^{12}$ \\ Email: udikjatmiko@kediri-uniska.ac.id
}

https://doi.org/10.30741/adv.v3i2.470

I N F O ART I K E L

Tanggal masuk :

23 Oktober 2019

Tanggal Revisi :

15 November 2019

Tanggal Diterima :

31 Desember 2019

\section{A B S T R A K}

Tujuan yang ingin peneliti harapkan dalam penelitian ini adalah untuk menjelaskan dan menganalisis persepsi jamaah mengenai layanan fasiltas yang dirasakan dan biaya perjalanan umroh terhadap keputusan memilih paket perjalanan umroh PT. Uda CS Holidays Cabang Kediri secara parsial maupun secara simultan antar variabel penelitian. Jumlah populasi yang diteliti sebanyak 612 jamaah, pengambilan sampel melalui Nonprobability sampling dengan metode sampel aksidental. Teknik analisis pada penelitian ini menggunakan uji regresi linear berganda. Berdasarkan hasil analis data dan pembahasan yang telah dilakukan secara keseluruhan dapat disimpulkan bahwa : (1) Fasilitas umroh tidak mempunyai pengaruh yang signifikan terhadap persepsi jamaah dalam memilih jasa umroh (2) Biaya perjalanan umroh memiliki pengaruh yang signifikan terhadap persepsi jamaah dalam memilih jasa umroh. (3) Secara simultan fasilitas dan biaya mampu memberikan pengaruh terhadap persepsi yang dimiliki jamaah dalam memilih umroh.

Kata Kunci : Fasilitas, Biaya Umroh dan Keputusan Memilih

\begin{abstract}
A B S T R A C T
This research aims to analyze and determine the effect of the facilities and costs of umrah travel on the choosing decision PT Uda CS Holidays Indonesia both partially and simultaneously. The population in this study is 612 pilgrims using non probability sampling techniques with accidental sampling as the approach. The data analysis techniques used are: (1) Validity and Reliability test, (2) Multiple Linear Regression Analysis, (3) F Test Analysis, (4) T-Test, and (5) Determinant Coefficient Test. The result of data analysis can be concluded as follows: (1) There is no partial positive and significant effect between the umrah facility variable on the choosing decision the Umrah package at PT Uda CS Holidays Indonesia (2) There is a positive and significant effect partially between the variable costs of umrah travel on the choosing decision Umrah package at PT Uda CS Holidays Indonesia. (3) Umrah facilities and the cost of joint umrah arrangements have a positive and significant effect on the choosing decision the Umrah package at PT. Uda CS Holidays Indonesia
\end{abstract}

Keywords: Facility, Cost, and Choosing Decision 


\section{PENDAHULUAN}

Perkembangan usaha dibidang jasa umroh dan haji pada akhir-akhir ini mengalami perkembangan yang begitu tinggi, jika dilihat dari aspek kualitas pelayanan fasilitas dan harga atau biaya yang dikeluarkan oleh para jemaah sangat mengalami perbandingan di setiap jasa agen travel haji dan umroh. Strategi dan penerapan juga manajemen yang baik, bertujuan untuk menggaet calon jamaah atau pemakai jasa travel. Rata-rata strategi dan manajemen travel haji dan umroh bisa dikatakan sama, hanya pada beberapa hal terjadi perbedaan Perbedaan tersebut bisa dilihat baik dari segi kualitas, dan juga kuantitas jamaah (Fadillah, 2019). Persepsi tersebut dipertegas oleh Nityasari \& Sutopo (2013) bahwa faktor kualitas layanan melalui tangible (bukti langsung) mampu memberikan kontribusi dan pengaruhnya kepada kepuasan pelanggan. Temuan dari penelitian tersebut juga didukung oleh Lempoy, Silvya, Sjendry (2015) menjelaskan secara singkat mengenai kepuasan pelanggan yang mampu dipengaruhi oleh fasilitas perusahaan. Sedangkan biaya umroh saat ini mengalami peningkatan dari penawaran biro jasa umrah, hal ini disebabkan oleh peta persaingan bisnis jasa travel, haji dan umroh yang sedang ramai di tataran masyarakat. Banyak perusahaan jasa dengan nama besar dan strategi marketing yang maksimal dengan menawarkan berbagai penawaran jasa umroh yang lebih menarik dibandingkan dengan jasa umroh yang telah lama ada, akan tetapi persepsi dan keinginan jamaah umroh lebih memilih perusahaan yang memiliki potensi strategi pemasaran yang mampu memberikan nilai kepuasan lebih kepada customernya dengan harapan para jemaah umroh tidak terkecewakan oleh pilihannya dalam memilih perusahaan jasa travel dan umroh. Merujuk pada hasil penelitian dari Chulaifi \& Endang (2018) harga tidak memiliki pengaruh terhadap kepuasaan konsumen dalam memilih jasa umroh. Akan tetapi hal tersebut berbeda dengan pendapat Lempoy et al, (2015) bahwa faktor harga mampu memberikan kotribusi pengaruhnya terhadap kepuasan konsumen.

Lingkungan bisnis saat ini berjalan penuh dengan ketidakpastian, bisnis yang dijalankan oleh perusahaan mampu bergerak dinamis dan fluktuatif dalam perkembangannya, maka dari itu perusahaan harus mampu bertindak secara cepat dan mampu bersikap secara cermat dalam memperhitungkan pergerakannya di pasar bisnis untuk menembus persaingan antar dunia bisnis. Perusahaan yang berhasil melalui tahap persaingan tentunya sangat memahami bagaimana mengantisipasi strategi pasar yang berubah-ubah, pemahaaman terkait tanggapan pelanggan akan persepsi kebutuhan yang cenderung berubah merupakan problematika yang harus dihadapi. Perilaku konsumen atau pelanggan ini akan menjadikan riset bagi perusahaan untuk terus menjadikan fokus perhatian yang berorientasi pada keburuhan pelanggan salah satunya dengan memberikan pelayanan yang terbaik kepada konsumennya, melalui pemberian fasilitas yang lebih baik sehingga mampu menjadi strategi pemasaran dalam memikat customernya untuk lebih percaya kepada perusahaan dan terus menggunakan jasa atau prosuk yang ditawarkan perusahaan. Dampak positifnya adalah terjaganya pertumbuhan perusahaan melalui eksistensi didalam persaingan bisnis yang sengit dan dalam hal penerapan kebijakan penentuan harga yang dapat mempengaruhi minat dan persepsi pelanggan pada umumnya (Ramadhani, 2017).

Keputusan konsumen dalam memilih poduk baik itu jasa atau barang salah satunya adalah pemberian fasiitas dari perusahaan. Keseluruhan sumberdaya fisik yang berada dalam perusahaan sebelum jasa tersebut ditawarkan kepada pelanggan harus diperhatikan secara maksimal oleh pihak perusahaan, proses pemberian fasilitas tersebut dimulai dengan penyediaan perlengkapan untuk menunjang kemudahan para pelanggan dalam mendapatkan jasa yang diinginkan, kemudahan mengakses serta dapat menimbulkan kemudahan juga dalam mendapatkan pelayanan, sehingga harapan pelanggan akan pemenuhan kebutuhan dapat terpenuhi sesuai dengan keinginginannya. Keberadaan fasilitas yang diberikan perusahaan kepada pelanggan dapat menjadi faktor pemuas kebutuhan, hal ini akan menanmkankan nilai tambah bagi para pelanggan, dapat meningkatkan ketertarikan pelanggan lebih kuat terhadap produk jasa yang ditawarkan. Saat ini pelanggan sudah semakin cerdas dalam menilai dan memperhitungkan produk mana yang akan dipilih untuk memenuhi kebutuhannya, mulai proses mengidentifikasi produk hingga pada tahap memutuskan untuk memilih selalu dilalui dengan proses selektif akan pertimbangan faktor-faktor yang meliputi isi produk yang ditawarkan perusahaan, semakin perusahaan memberikan fasilitas secara lengkap 
konsumen juga akan berfikir semakin loyal untuk memilih produk yang ditawarkan tersebut secara terus menerus dan berkelanjutan (Tjiptono, 2012).

Problematika lain patut untuk menjadi pertimbangan dalam mengembangkan suatu bisnis jasa adalah biaya dari produk yang ditawarkan. Biaya yang dipatok oleh perusahaan terhadap produk yang akan di tawarkan atau dijual kepada masayarakat mempunyai keterlibatan atau kepentingan yang sangat krusial, karena konsumen dalam memutuskan untuk memilih barang atau jasa selalu memikirkan aspek biaya yang akan mereka keluarkan untuk memperoleh produk sesuai dengan keinginan. Setiap perusahaan senantiasa memberikan informasi mengenai biaya atas produk atau jasa yang ditawarkan kepada pelanggannya, informasi mengenai biaya yang aktual, sesuai dengan spesifikasi produk tersebut merupakan bagian dari fungsi manajemen yang dianggap penting dalam usaha mempengaruhi perilaku konsumen. Harga atau biaya atas suatu produk yang dikeluarkan oleh pelanggan, dapat dikatakan bahwa suatu pengeluaran yang berupa nominal baik dilakukan oleh individu atau perusahaan atau kelompok dengan tujuan mencari manfaat lebih dari aktivitas produk yang dipilih untuk memenuhi harapannya. Setiap aktivitasnya konsumen dalam mendapatkan barang atau jasa dari perusahaan tertentu pasti mengeluarkan sejumlah biaya atau nominal untuk berbagai macam fasilitas dari produk yang diinginkan tersebut, termasuk konsumen yang memutuskan untuk memilih jasa perjalanan umroh (Raharjaputra, 2011).

Jasa perjalanan umroh kian marak di tengah-tengah masyarakat hari ini, bisnis penyedia jasa perjalanan umroh saat ini merupakan bisnis yang banyak diminati. Menurut Syariat Islam, umroh merupakan ibadah yang saat ini dianjurkan dan memiliki keutamaan dalam menjalankannya berdasarkan tata cara dan prosedur tertentu (thawaf dan Sa'i). Aktivitas ibadah umroh merupakan suatu kegiatan ibadah bagi umat muslim yang pelaksanaannya dan tata cara peribadahannya hampir sama dengan pelaksanaan ibdaha haji di tanah suci Mekkah. Akan tetapi, dalam pelaksanaanya ibadah umroh berbeda dengan haji karena dapat dilakukan pada setiap waktu tertentu dan mempunyai rukun dan tata cara yang membedakannya. Oleh karena itu, pada masa sekarang banyak bisnis yang mencium peluang itu untuk mendirikan biro atau paket perjalanan umroh. Animo masyarakat yang besar dalam usaha mendapatkan kesempatan untuk berangkat umroh menjadikan beberapa pihak tertentu bersaing untuk mempengaruhi persepsi konsumen dalam memilih paket umroh yang mampu memberikan kenyamanan kepada masyarakat atau konsumen. Fenomena yang terjadi saat ini mengatakan bahwa banyaknya bermunculan bisnis perjalanan umroh di Wilayah Kediri dan sekitarnya ini antara lain disebabkan meningkatkanya respon masyarakat untuk menunaikan ibdah umroh. Perusahaan jasa yang bergerak di bidang bisnis jasa perjalanan umroh, dituntut selalu melakukan pengembangan pada strategi pemasaran khususnya melalui pemberian fasilitas umroh dan biaya perjalanan yang dirasa dapat membantu masayarakat untuk mendapatkan jasa umroh tersebut (Simpu Kemenag, 2019).

Salah satu perusahaan yang selalu mengembangkan strategi pemasaran jasa perjalanan umroh tersebut yakni PT. Uda CS Holidays Indonesia adalah perusahaan yang menawarkan produk perjalanan umroh dengan sistem pembiayaan umroh. Pembiayaan umroh yang dijalankan oleh PT. Uda CS Holidays Indonesia dalam memberikan penawaran jasa umroh kepada jamaahnya, dilakukan dengan pemberian jaminan atas kesehatan, keamanan dan aspek kenyamanan bagi para calon jamaah ibadah umroh. Pelaksanaannya dan penerapananya perusahaan tersebut menawarkan produk perjalanan umroh dengan sistem pembiayaan yang dapat di angsur oleh calon konsumen atau konsumen yang memilih paket perjalanan umroh atau biasa disebut dengan dana talangan. Pembiayaan pada produk talangan umroh yang diberikan pihak perusahaan kepada calon jamaah dengan prosedur mencicil biaya umroh yang telah disepakati dengan pihak perusahaan. Jika dibandingkan dengan produk pembiayaan lain, dana talangan umroh ini memberikan sedikit resiko dana yang macet, namun dari sisi keruntungan akan memberikan kelebihan baik bagi customer (pelanggan). Akan tetapi, dalam proses pembiayaan dana talangan umroh ini masih terdapat kelemahan dalam prosedur pemberian dan secara administrasi kerangka prosedur pemberiannya masih membuat para jemaah umroh merasa kebingungan terlebih terkait masalah kelengkapan berkas dan data probadi. 
Masalah lain yang muncul berdasarkan pengamatan yang telah dilakukan dalam proses pengidentifikasian masalah di objek penelitian dapat dijelaskan bahwa klien atau masyarakat yang memutuskan memilih paket perjalanan umroh ini sebagaian berfikir adanya problem terkait fasilitas yang dijanjikan dalam brosur atau pamfletnya. Perusahaan memberikan informasi bahwa terdapat penginapan atau hotel yang berdekatan dengan lokasi umroh, akan tetapi yang dirasakan adalah ketidak sesuaian jarak penginapan. Selain itu masalah biaya juga menjadi bahan pertimbangan untuk terus melaksanakan kegiatan perjalanan umroh. Temuan dalam penelitian ini menjelaskan bahwa sering kali tidak terjadi kesepakatan biaya perjalanan antara pihak pengelola dan travel yang menjadi akomodasi pemberangkatan. Pihak pengelola sebelumnya telah menginfokan kepada calon konsumen mengenai paket perjalanan umroh, akan tetapi pihak akomodasi dalam hal ini penyelenggara travel memberikan biaya tambahan pada saat MOU dengan pengelola, hal ini dirasa bisa menjadikan pihak konsumen yang menaruh kepercayaannya berpikir ulang untuk memilih paket perjalanan umroh di PT. Uda CS Holidays Indonesia. Berdasarkan kajian problematika dalam yang telah dijabarkan di atas, dapat disampaikan mengenai fokus permasalahan sebagai berikut : 1) Adakah pengaruh pemberian fasilitas umroh terhadap persepsi jamaah dalam memilih perjalanan umrah. 2) Adakah pengaruh biaya umroh dalam mempengaruhi persepsi jamaah untuk memilih perjalanan umroh. 3) Adakah hubungan fasilitas umroh dan biaya umroh dalam mempengaruhi persepsi jamaah memilih perjalanan umroh.

Fasilitas yang diberikan perusahaan kepada konsumen merupakan sesuatu yang berupa perlengkapan fisik yang diberikan oleh penyedia jasa untuk mendukung ketersediaan kebutuhan konsumen. Perlengkapan fisik tersebut didesain oleh perusahaan secara sengaja untuk memperolah perhatian dari konsumen, dengan tujuan memberikan pelayanan yang terbaik untuk konsumennnya sehingga dapat menumbuhkan rasa puas secara keseluruhan (Kotler, 2013). Pemberian fasilitas yang baik oleh perusahaan dalam bentuk tampilan-tampilan, sarana pendukung dan seluruh keadaan lingkungan perusahaan yang mampu memberikan pandangan kepada konsumen secara nyata agar semakin yakin dan percaya telah memilih perusahaan sebagai solusi dari pemenuhan kebutuhannya baik dari segi bangunan, ketersediaan ruangan, tata letak kantor dan suhu ruang yang menyejukkan. Pemberian fasilitas yang memadai akan dipergunakan oleh konsumen secara maksimal, sehingga memunculkan kepuasan yang akan melahirkan perilaku pengambilan keputusan yang tinggi dalam mengkonsumsi produk baik barang atau jasa, elain itu dapat mendorong konsumen untuk merekomendasikan pemilihannya tersebut kepada pihak lain baik keluarga, saudara maupun masyarakat sekitar tempat tinggal konsumen yang telah merasakan fasilitas tersebut (Lupiyoadi, 2012). disisi lain, faktor non fisik juga menjadi bahan pertimbangan seorang konsumen dalam proses keputusan memilih seperti kenyamanan, keamanan, jaminan atas produk jasa yang dirasakan, minimnya tekanan dari perusahaan, bahkan sampai pada kemudahan mengurus administrasi yang tidak berbelit-belit. Fasilitas non fisik yang dimaksud adalah segala hal yang bisa dirasakan dan dinikmati dengan tujuan memberikan pelayanan yang mudah kepada pelanggan (Memah, Altje, Paulina, 2015). Atas dasar teori-teori dan oendapat di atas dapat dijelaskan bahwa keberadaan fasilitas yang memadai sangat diharapkan oleh konsumen dalam proses pemenuhan kebutuhan akan suatu produk baik barang maupun jasa.

Pembiayaan yang diterapkan oleh PT. Uda CS Holidays Indonesia dalam menawarkan produk umroh kepada konsumen melalui pembiayaan ijarah atau dengan jasa sewa melaui strategi dana talangan. Permasalahan biaya umroh juga menjadi faktor penentu konsumen dalam memilih jasa perjalanan umroh pada perusahaan penyedia jasa tersebut. Dalam proses pemberian pembiayaan oleh penyedia jasa patut dipertimbangkan proses analisis pembiayaan, dimana perusahaan melakukan telaah secara mendalam mengenai aspek-aspek yang mendasari setiap konsumen atau jamaah untuk dibiayai oleh perusahaan. Aspek pertama yang dilakukan perusahaan adalah dengan memperhatikan niat, kemauan dan taraf kemampuan konsumen atau jamaah tersebut untuk memenuhi cicilan atau membayar dana talangan umroh yang nanti akan diberikan. Aspek yang kedua adalah proses analisis terhadap kegiatan atau pekerjaan bagi calon konsumen yang akan dbiayai, karena faktor perekonomian menjadi kunci konsumen dalam unsur kemampuan membayar angsuran dana talanagan tersebut. Pada kenyataannya saat ini program pembiayaan 
juga penuh dengan resiko tidak tertagihnya cicilan atau biasa disebut kredit macet atau kredit bermasalah, maka dari itu analisis resiko pembiayaan perlu dilakukan untuk menghindari resiko yang tidak diinginkan perusahaan. Menurut Hurriyati (2012) biaya merupakan nominal yang dikeluarkan oleh konsumen dalam usaha mendapatkan produk baik barang atau jasa sesuai dengan kebutuhannya. Biaya menjadi faktor yang paling dominan bagi persepsi pelanggan untuk selalu menjadi pikiran utama sebelum membeli dari pada melihat kualitas produk yang akan dipilih, karena hal ini berhubungan dengan kemampuan konsumen untuk mendapatkan sesuati yang sesuai dengan seleranya. Maka dari itu perusahaan penyedia jasa, harus mampu mengambil kebijakan penentuan biaya yang sesuai dengan manfaat yang diberikan kepada konsumen, biaya juga mampu bersaing dengan perusahaan lain, sehingga biaya yang ditetapkan perusahaan mampu memberikan informasi yang jelas atas sebuah produk yang akan ditawarkan oleh perusahaan. Secara sederhana biaya atau harga dari sebuha produk diartikan sejumlah nominal uang (dalam satuan mata uang tertentu) atau dalam bentuk hal lain seperti emas, surat-surat berharga yang memiliki kegunaan secara mendalam untuk memperoleh jasa yang diinginkan para konsumen (Tjiptono, 2012).

\section{METODE PENELITIAN}

Jenis penelitian ini merupakan pendektan kuantitatif melalui pendekatan eksplanasi (penjabaran). Jumlah populasi dalam penelitian semua jamaah yang telah memilih dan merasakan paket perjalanan umroh pada perusahaan jasa dan travel PT. Uda CS Holidays Indonesia. Untuk pengambilan sampel penelitian menggunakan pendekatan nonprobability sampling dengan melalui teknik sampling aksidental merupakan teknik pengambilan sampel yang dilakukan atas dasar suatu kebetulan kepada responden yang dijumpai dilokasi penelitian (Sugiyono, 2016). Berdasarkan perhitungan yang telah dijelaskan tersebut, maka jumlah sampelnya sebanyak 86 responden. proses pengolahan data dilakukan dengan penyebaran kuisioner dan kemudian dilakukan tabulasi serta pengolahan data, untuk teknik analisis data dalam penelitian ini menggunakan uji regresi linear berganda yang dikerjakan oleh peneliti melalui aplikasi stastical package for the social sciences versi 23.0. Hal ini dilakukan guna menguji hipotesis penelitian yang telah dilakukan pada proses pengumpulan data penelitian, uji hipotesis tersebut adalah uji t statistik dan uji $\mathrm{F}$ antar variabel penelitian (Ghozali, 2011).

\section{HASIL DAN PEMBAHASAN}

Berdasarkan penelitian dan pengolahan data yang telah diperoleh melalui SPSS versi 23.0, secara rinci disampaikan hasil penelitian bahwa persepsi jamaah umroh mengenai fasilitas dan biaya

Tabel 1. Hasil Perhitungan Analisis Regresi Antar Variabel

\begin{tabular}{lllll}
\hline & B & Beta & t & Sig. \\
\hline (Constant) & 10.341 & & 3.187 & .002 \\
Fasilitas Umroh & -.072 & -.076 & -1.182 & .241 \\
Biaya Perjalanan Umroh & .812 & .856 & 13.236 & .000 \\
$\mathrm{R}=0,883$ & \multicolumn{5}{c}{ Fhitung $=94.086$} \\
Adjusted $\mathrm{R}^{2}=0,687$ & \multicolumn{5}{c}{ Signifikasi $=0,000$} \\
\hline
\end{tabular}

Sumber : Diolah Peneliti, 2019.

Hasil pengolahan data dan temuan perhitungan di atas, maka dijelaskan bahwa diperoleh nilai regresi linear berganda sebagai berikut: $\mathrm{Y}=10,341-0,072 \mathrm{X}_{1}+0,812 \mathrm{X}_{2}$, Artinya besarnya pengaruh variabel fasilitas umroh dan biaya perjalanan umroh yang diterapkan perusahaan jika tidak mengalami perubahan (konstan), maka keputusan konsumen dalam memilih paket umroh sebesar 10,341satuan. Untuk fasilitas diperoleh nilai regresinya negatif, hasil temuan ini menjelaskan bahwa jika fasilitas umroh ditingkatkan setiap 1 satuan, maka besarnya keputusan memilih paket umroh mengalami penurunan persepsi jamaah sebesar - 0,072 dengan arah yang berbeda. Nilai regresi biaya perjalanan umroh mempunyai nilai positif, dapat diartikan bahwa hubungan variabel tersebut searah. jika kualitas biaya perjalanan umroh yang diberikan oleh 
perusahaan ditingkatkan 1 atuan, maka besarnya keputusan memilih paket umroh (Y) akan mengalami peningkatan dengan nilai sebesar 0,812 satuan. Nilai koefisien determinasi $\left(\mathrm{R}^{2}\right)$ diperoleh hasil senilai 0,687 satuan artinya kontribusi faslitas umroh dengan biaya perjalanan umroh terhadap keputusan memilih paket umroh di PT. Uda CS Holidays Indonesia memiliki nilai sebesar 49,2\% sedangkan sisanya berasal dari variabel dan indikator lain yang tidak diteliti.

Hasil perhitungan nilai uji $t$ tentang fasilitas umroh $\left(X_{1}\right)$ dengan membandingkan nilai $t_{\text {hitung }}>t_{\text {tabel }}$. Hasil perhitungan adalah -1.182> 1,989 maka Ho diterima dan Ha tidak diterima. Perhiutngan nilai signifikannya diperoleh $(0,241)<0,05$ dapat diartikan bahwa tidak terdapat pengaruh yang positif dan signifikan secara parsial antara variabel fasilitas umroh $\left(\mathrm{X}_{1}\right)$ terhadap keputusan memilih paket umroh di PT. Uda CS Holidays Indonesia. Berdasarkan perhiungan tersebut dapat disimpulkan bahwa hipotesis operasional yang pertama dinyatakan ditolak dan secara empiris tidak dapat dibuktikan. Hasil uji t secara parsial tentang variabel biaya perjlaanan umroh $\left(\mathrm{X}_{2}\right)$ dengan membandingkan nilai $t_{\text {hitung }}>t_{\text {tabel }}$. Hasil perhitungan adalah 13,236 >1,989 maka hipotesis awal (Ho) ditolah dan hipotesis alternatif (Ha) diterima. Nilai signifikannya sebesar 0,000 lebih kecir dari taraf signifikan 0,05 yang artinya terdapat pengaruh yang positif dan signifikan secara parsial antara variabel biaya perjlaanan umroh $\left(\mathrm{X}_{2}\right)$ terhadap keputusan memilih paket umroh di PT. Uda CS Holidays Indonesia. Berdasarkan perhitungan tersebut dideskripsikan bahwa biaya perjalanan umroh merupakan variabel yang paling dominan mempengaruhi persepsi jamaah dalam memilih umroh.

Pengujian antar variabel secara serempak dalam penelitian ini digunakan Uji F. Dalam penelitian ini $\mathrm{F}_{\text {tabel }}$ diperoleh dengan melihat df pembilang (k-1) dan df penyebut (n-k-1) pada tabel $\mathrm{F}$, $(\mathrm{k}$ : jumlah variabel, $n:$ Sampel ). Adapun perhitungan $F_{\text {tabel }}$, Df pembilang $=3-1=2$, Df penyebut $=$ $86-3-1=82$. Diperoleh nilai $F_{\text {tabel }}=3,108$. Berdasarkan hasil perhitungan di atas, menunjukkan bahwa $F_{\text {hitung }}$ sebesar 94,086 lebih besar dari $F_{\text {tabel }}$ sebesar 3,108. dengan nilai signifikan $F$ sebesar $0,000<$ sig. 0,05. Berdasarkan perhitungan tersebut, maka dapat dijelaskan bahwa Ha diterima dan Ho ditolak. Hal tersebut dapat dijelaskan bahwa fasilitas umroh $\left(\mathrm{X}_{1}\right)$ dan biaya perjlaanan umroh $\left(\mathrm{X}_{2}\right)$ secara simultan mampu memberikan kontribusi pengaruhnya terhadap persepsi jamah dalam memilih paket umroh di PT. Uda CS Holidays Indonesia.

Persepsi Mengenai Fasilitas Umroh terhadap Perilaku Jamaah Dalam memilih Paket Perjalanan Umroh Pada PT. UDA CS HOLIDAYS INDONESIA. Berdasarkan hasil penelitian yang telah dilakukan diperoleh hasil bahwa nilai $\mathrm{t}_{\text {hitung }}>\mathrm{t}_{\text {tabel }}$. Hasil perhitungan adalah $-1.182>1,989$ maka Ho diterima dan Ha ditolak. Nilai signifikan. $\mathrm{t}(0,241)<0,05$ yang artinya tidak terdapat pengaruh yang positif dan signifikan secara parsial antara variabel fasilitas umroh $\left(\mathrm{X}_{1}\right)$ terhadap keputusan memilih paket umroh di Pada PT. UDA CS HOLIDAYS INDONESIA. Penelitian ini memperoleh bukti empiris yang menunjukkan bahwa fasilitas perjalanan umroh yang diberikan oleh pihak perusahaan sebagai strategi untuk mempengaruhi persepsi konsumen dalam hal ini jamaah umroh tidak memiliki pengaruh terhadap keputusan konsumen dalam memilih paket umroh tersebut, hal ini mengindikasikan bahwa fasilitas yang diberikan oleh perusahaan dalam penerapannya sudah sesuai harapan atau keinginan para konsumen jika dilihat dari persepsi yang dikembangkan. Fasilitas yang diberikan indikator Administrasi, bimbingan manasik umroh, transportasi, akomodasi, konsumsi, pemeriksaan kesehatan. Hal tersebut dapat dijelaskan secara singkat bahwa persepsi jamaah terhadap pemberian fasilitas dalam memilihi paket umroh sudah berjalan sesuai dengan keinginan para jamaah, dianggap sudah mampu memenuhi kebutuhan para jamaah dalam proses pemilihan jasa pakaet perjalanan umroh. Hasil penelitian ini tidak sejalan dengan penelitian yang dilakukan oleh Fadillah (2019), Nityasari \& Sutopo (2013) serta Lempoy et al (2015) yang menyatakan bahwa fasilitas berpengaruh terhadap kepuasan pelanggan. dapat diartikan bahwa hasil penelitian ini tidak mendukung kajian penelitian terdahulu yang telah direkomendasikan sebelumnya.

Persepsi Mengenai Biaya Perjalanan Umroh (X2) Terhadap Perilaku Jamaah Dalam memilih Paket Perjalanan Umroh Pada PT. UDA CS HOLIDAYS INDONESIA. Berdasarkan hasil penelitian 
yang telah dilakukan diperoleh hasil nilai $t_{\text {hitung }}>t_{\text {tabel }}$. Hasil perhitungan adalah 13,236 $>1,989$ maka Ho ditolak dan Ha diterima. Nilai signifikan. $t(0,000) \leq 0,05$ yang artinya terdapat pengaruh yang positif dan signifikan secara parsial antara variabel biaya perjlaanan umroh $\left(\mathrm{X}_{2}\right)$ terhadap terhadap keputusan memilih paket umroh di PT. UDA CS HOLIDAYS INDONESIA. Nilai regresi variabel biaya perjalanan umroh mempunyai nilai positif, dapat diartikan bahwa hubungan variabel tersebut searah. jika biaya ditingkatkan, maka persepsi konsumen dalam mengambil keputusan memilih paket umroh tersebut juga akan mengalami peningkatan. hasil penelitian ini mengindikasikan bahwa biaya perjalanan umroh merupakan faktor yang utama dalam diri konsumen sebelum memutuskan untuk memilih jasa umroh tersebut. Biaya perjalanan umroh yang ditawarkan oleh perusahaan dalambentuk pembiayaan kepada konsumen dalam penerapannya juga menjadi faktor penentu dalam memilih paket umroh ini, artinya rata-rata konsumen akan mengambil jasa pembiayaan umroh ini dengan membandingkan terlebih dahulu dengan jasa umroh lain untuk mencari informasi lebih detail mengenain biaya perjalanan umroh. Hal ini yang akan menjadi strategi perusahaan untuk lebih memperhatikan kebijakan pembiayaan yang lebih profesional dan terjangkau sesuai persepsi konsumen tersebut. Hasil penelitian yang telah dilakukan ini didukung oleh Lempoy et all (2015) yang memberikan pendapat bahwa biaya atas jasa yang diberikan suatu perusahaan berpengaruh signifikan terhadap keputusan konsumen dalam memilih produk jasa. Akan tetapi Chulaifi \& Endang (2018) menyatakan bahwa harga tidak berpengaruh terhadap kepuasan konsumen.

\section{KESIMPULAN}

Berdasarkan pembahasan yang telah dilakukan serta kajian hipotesis yang dikembangkan dalam penelitian ini, maka dapat di jelaskan mengenai kesimpulan dari pelaksanaan penelitian ini sebagai berikut : (1) Fasilitas umroh tidak mempunyai pengaruh yang signifikan terhadap persepsi jamaah dalam memilih jasa umroh (2) Biaya perjalanan umroh memiliki pengaruh yang signifikan terhadap persepsi jamaah dalam memilih jasa umroh. (3) Secara simultan fasilitas dan biaya mampu memberikan pengaruh terhadap persepsi yang dimiliki jamaah dalam memilih umroh Pada PT. UDA CS HOLIDAYS INDONESIA.

\section{DAFTAR PUSTAKA}

Chulaifi, M, I., Endang, S. (2018). Pengaruh Kualitas Pelayanan, Persepsi Harga Dan Kepercayaan Terhadap Kepuasan Konsumen Jasa Travel Umrah Dan Haji Pada PT. Sebariz Warna Berkah Di Surabaya. Jurnal Hasil Penelitian LPPM Untag Surabaya. 03, 01. Diakses dari http://jurnal.untag-sby.ac.id/index.php/jhp17/issue/view/144

Fadillah, L. (2019). Strategi Dan Manajemen Travel Haji Dan Umroh (Studi Analisis Persaingan Travel Haji Dan Umroh Kota Medan Dalam Pelayanan dan Kualitas Untuk Meningkatkan jumlah Konsumen. Al-Muamalat : Jurnal Hukum Ekonomi Syariah. 4, 01. 1-24. Diakses dari https://journal.iainlangsa.ac.id/index.php/muamalat/article/view/775

Ghozali, I. (2011). Aplikasi Analisis Multivariate dengan program SPSS. Semarang: Universitas Diponegoro.

Hurriyati, R. (2012). Bauran Pemasaran dan Loyalitas Konsumen. Bandung: Alfabeta.

Kemenag. (2019). Pencarian PPIU (Penyelenggara Perjalanan Ibadah Umrah). tulisan pada https://simpu.kemenag.go.id/home/travel.

Kotler, P. (2013). Dasar-dasar Pemasaran. Jakarta: Intermedia.

Lempoy, N, C., Silvya, L, M., Sjendry, S, R, L. (2015). Pengaruh Harga, Lokasi, Dan Fasilitas Terhadap Keputusan Menggunakan Jasa Taman Wisata Toar Lumimuut (Taman Eman) Sonder. Jurnal EMBA: Jurnal Riset Ekonomi, Manajemen, Bisnis dan Akuntansi. 3, 1. 1072-1083. DOI : https://doi.org/10.35794/emba.v3i1.7867

Lupiyoadi, R. (2012). Manajemen Pemasaran Jasa Teori dan Praktik. Jakarta: Salemba Empat.

Memah, D., Altje, T., Paulina V, R .(2015). Pengaruh Strategi Promosi, Harga Lokasi Dan Fasilitas Terhadap Keputusan Pembelian Rumah Di Citraland Manado. Jurnal EMBA. 3, 1. 1263-1273. DOI : https://doi.org/10.35794/emba.v3i1.8285 
Nityasari, A. H., Sutopo. (2013). Analisis Pengaruh Kualitas Pelayanan Terhadap Kepuasan Pengguna Jasa Jamaah Umroh Tahun 2010-2012 (Studi Kasus Pada PT Fatimah Zahra Semarang). Diponegoro Journal of Management. 1, 2. 82-90. Diakses dari https://ejournal3.undip.ac.id/index.php/djom/article/view/9011

Raharjaputra, H, S. (2011). Manajemen Keuangan dan Praktis. Jakarta: Salemba Empat.

Ramadhani, N, H. (2017). Pengaruh Kualitas Pelayanan Terhadap Kepuasan Pelanggan PT. Basmatour \& Travel. Diakses dari Universitas Muhammadiyah Malang, Institusional Repository, http://eprints.umm.ac.id/34747/.

Sugiyono. (2016). Metode Penelitian Kuantitatif Kualitatif dan H\&D. Bandung: Alfabeta.

Tjiptono, F. (2012). Pemasaran Strategik. Yogyakarta: ANDI. 